\title{
Acholeplasma morum, a New Non-Sterol-Requiring Species
}

\author{
DAVID L. ROSE, ${ }^{1}$ JOSEPH G. TULLY, ${ }^{1}$ AND RICHARD A. DEL GIUDICE ${ }^{2}$ \\ Laboratory of Infectious Diseases, National Institute of Allergy and Infectious Diseases, Bethesda, \\ Maryland 20205, ${ }^{1}$ and Biological Carcinogenesis Program, Frederick Cancer Research Center, Frederick, \\ Maryland $21701^{2}$
}

\begin{abstract}
Two acholeplasmas recovered from contaminated cell cultures or commercial fetal bovine serum were found to be similar in biochemical and serological properties. The organisms, although not requiring serum or cholesterol for growth, did require a supplement of $0.5 \%$ albumin and $10 \mu \mathrm{g}$ of palmitic acid per $\mathrm{ml}$ to a serum-free medium for sustained growth in the absence of sterols. The growth of both organisms was inhibited in medium containing $20 \%$ horse serum, although smaller amounts of horse serum or $20 \%$ fetal bovine serum did not exert inhibitory effects. The two strains possessed biochemical properties typical of other nonsterol-requiring members of the Mycoplasmatales, and they were serologically distinct from seven established Acholeplasma species. On the basis of these findings and other morphological, biological, and serological properties of the organisms, it is proposed that these organisms represent a new species, Achole. plasma morum. Strain 72-043 (=ATCC 33211) is the type strain.
\end{abstract}

The acholeplasmas are a group of non-sterolrequiring members of the Mycoplasmatales found in a large number of hosts and in some plants (25). Currently, seven species of Achole. plasma are recognized. The acholeplasmas differ from other members of the Mycoplasmatales in a number of molecular, genetic, and biochemical characteristics $(3,12,15-18,20)$, whereas individual Acholeplasma species are differentiated on a limited number of biochemical properties and upon serological characteristics (25).

In 1970, Schwöbel and Leach (23) reported the recovery of a non-sterol-requiring organism (strain S2) from a primary bovine kidney cell culture. This cytopathic organism was found to be serologically distinct from Acholeplasma laidlawii (then known as Mycoplasma laidlawii) and from a number of other members of the Mycoplasmatales found in contaminated cell cultures or in bovine hosts. The S2 strain was examined subsequently in our laboratory in Bethesda, Md., and was found to be serologically unrelated to A. laidlawii, Acholeplasma granularum, or other newly established Acholeplasma species. In 1972, one of us (R.A.DG.) recovered an untypable acholeplasma from a bottle of commercial fetal bovine serum. This strain (72-043) was also found to be serologically distinct from all of the established species of Acholeplasma represented in the Bethesda laboratory. Several years later, comparative tests on a number of unclassified acholeplasmas in our collection indicated not only that the S2 and 72-043 strains were serologically related, but also that they shared a number of other growth and biochemical characteristics. In view of some of the known difficulties in separating acholeplasmas by current serological techniques (25), in particular the preparation of a potent and specific antiserum, we felt that the S2 and 72-043 strains should be subjected to nucleic acid hybridization comparisons with other species of Acholeplasma. The results of this comparison (2) indicated that these two strains were clearly related to each other but were distinct from other presently recognized Acholeplasma species. This paper defines the basic characteristics of these organisms. Since this information further confirms their unique biological and serological properties, we hereby propose that these organisms be given taxonomic status as a new Acholeplasma species.

\section{MATERLALS AND METHODS}

Acholeplasma strains. Details of the primary isolation of strain S2 from bovine kidney cultures have been given previously (23). Strain 72-043 was isolated from a commercial lot of fetal bovine serum, using a detection technique whereby test serum was added at a 20\% concentration to conventional mycoplasma broth medium (4). The reference acholeplasmas and other members of the Mycoplasmatales used in this study for serological and biological comparisons with strains S2 and 72-043 were stock cultures maintained in the Mycoplasma Section of the Laboratory of Infectious Diseases, National Institutes of Health, Bethesda, Md.

Media and cultivation procedures. The isolates were grown on mycoplasma broth base (BBL Microbiology Systems, Cockeysville, Md.) supplemented with $10 \%$ of a mixture of fresh $25 \%$ yeast extract 
(Microbiological Associates, Bethesda, Md.), 1\% bovine serum fraction (Difco Laboratories, Detroit, Mich.), and $500 \mathrm{U}$ of penicillin $\mathrm{G}$ per $\mathrm{ml}$. A serum-free medium was prepared from the above-mentioned formula by replacing the bovine serum fraction with a supplement containing $0.5 \%$ bovine albumin, $10 \mu \mathrm{g}$ of palmitic acid per $\mathrm{ml}, 0.5 \%$ glucose, and $0.002 \%$ phenol red. Serum-containing media were prepared by adding various sterile animal sera to the broth base-yeast extract combination. The sera included regular horse serum and agamma horse serum (Flow Laboratories, Rockville, Md.), newborn calf serum and agamma calf serum (Microbiological Associates), and fetal bovine serum (Sterile Systems, Logan, Utah). Solid medium was prepared by adding $0.8 \%$ Noble agar (Difco) to the broth base before autoclaving. Agar cultures were grown at $37^{\circ} \mathrm{C}$, either in an atmosphere of $95 \%$ nitrogen and $5 \%$ carbon dioxide or under aerobic conditions. On occasion, the strains were grown at room temperature $\left(23^{\circ} \mathrm{C}\right)$. Each strain was purified by a $3 \times$ filtration-cloning technique (24) before biochemical and serological tests.

Reversion studies. Antibiotic-free medium containing bovine serum fraction supplement was used to detect possible reversion of strains $72-043$ and S2 to bacteria. Seven passages on this medium were performed, and the cultures were transferred to blood agar plates at each passage. The agar plates were incubated at $37^{\circ} \mathrm{C}$ and examined for bacterial colonies.

Morphology. Broth cultures of the organism (72043) were examined by dark-field microscopy and Gram staining. An electron microscopic ultrastructural study was performed with procedures described previously (7).

Filtration studies. A 24-h broth culture of strain 72-043 was examined for passage through a series of membrane filters with graded pore diameters (450-, $300-, 220$-, and $100-\mathrm{nm}$ average pore diameters) by techniques outlined earlier (26).

Tests for biological and biochemical properties. Sterol requirement was determined by a broth culture method (20). A $2 \%$ inoculum was used, and the cultures were harvested after 7 days of incubation at $37^{\circ} \mathrm{C}$. Susceptibility to $1.5 \%$ digitonin was assayed by a plate method, utilizing mycoplasma agar containing $20 \%$ fetal bovine serum (11). The procedures used to determine carbohydrate fermentation, arginine and urea hydrolysis, tetrazolium reduction, serum liquefaction, and film and spot reactions have been described earlier (1). Hydrolysis of esculin was assayed by the method of Williams and Wittler (30), and arbutin hydrolysis was tested by the technique of Ernø and Stipkovits $(10,25)$. Phosphatase activity was determined by the method of Bradbury (5). Methods used to test for production of carotenoids have been given earlier (27). Hemadsorption was detected by the procedure of Manchee and Taylor-Robinson (14).

Serological tests. Hyperimmune antisera for serological testing were prepared to the organisms listed in Table 1. Part of the collection represents antisera prepared as part of the National Institutes of Health mycoplasma reference reagent program (8). The methods used in preparing the antisera for the remaining organisms have been given elsewhere (26). Disk growth inhibition tests (6) were performed with 24 -h- old cultures of strains $72-043$ and $S 2$ grown on the serum fraction medium. Antigens were tested at 1:100 and 1:1,000 dilutions against undiluted antisera. Plate immunofluorescence antibody tests were performed by a direct method (9), using fluorescein-conjugated antisera to the organisms listed in Table 1.

Polyacrylamide gel electrophoresis. Acholeplasmas grown in $1 \%$ bovine serum fraction broth were sedimented by centrifugation, and the cell proteins were solubilized in phenol-acetic acid-water (2:1:0.5, $\mathrm{wt} / \mathrm{vol} / \mathrm{vol}$ ). The extracts were then compared in polyacrylamide tube gels $(19,21)$.

DNA characteristics. The deoxyribonucleic acid (DNA) guanine-plus-cytosine content of both strains (72-043 and S2) was determined from the melting temperature, using techniques described earlier (13, 22). The DNA of Spiroplasma citri, with guanineplus-cytosine content of $26 \mathrm{~mol} \%$, was utilized as a reference standard in the procedure.

\section{RESULTS}

Morphological and cultural properties. Broth cultures of strains 72-043 and S2 examined by dark-field microscopy showed predominately round and coccobacillary forms, with some beaded filaments and star forms in older cultures. Cells stained by the Gram technique revealed gram-negative pleomorphic structures similar to those observed in dark-field preparations. Electron microscopic examination of thin sections of cell pellets showed a pleomorphic organism with a unit membrane and no evidence of cell wall material outside the membrane (Fig. 1). Broth cultures became turbid in $18 \mathrm{~h}$ at $37^{\circ} \mathrm{C}$ and in $48 \mathrm{~h}$ at $23^{\circ} \mathrm{C}$. The organisms grew well in medium containing $1 \%$ bovine serum fraction or in broth supplemented with $20 \%$ concentrations of fetal bovine serum or agamma horse serum (Table 2). However, very poor growth, or no growth, occurred in broth medium containing $20 \%$ horse serum, $20 \%$ newborn calf serum, or $20 \%$ agamma calf serum. Decreasing the quantity of horse serum in the broth to 5 or $10 \%$, or reducing the newborn calf serum to $5 \%$, removed the inhibition expressed at the higher serum levels. Adequate growth could be maintained in a serum-free medium only when it was supplemented with albumin and palmitic acid. Colonies on serum-free agar were small (60 to 100 $\mu \mathrm{m})$ and very rough or irregular (Fig. 2A). Colonies on the bovine serum fraction agar were slightly larger (100 to $150 \mu \mathrm{m}$ ) and also displayed the rough mulberry-like appearance seen on serum-free agar (Fig. 2B). Optimum growth on agar occurred after $48 \mathrm{~h}$ at $37^{\circ} \mathrm{C}$ under anaerobic conditions.

Reversion studies. Cultures maintained in antibiotic-free broth medium for seven passages showed no reversion to bacterial forms, either 
TABLE 1. Mycoplasmatales strains and antisera used in serological tests

\begin{tabular}{|c|c|c|c|}
\hline Species (strain) & Source $^{a}$ & Species (strain) & Source $^{a}$ \\
\hline Acholeplasma axanthum (H86N) & MS-LID & M. felis (Cat 27) & MS-LID \\
\hline A. equifetale (N93) & MS-LID & M. fermentans (PG-18) & $\mathrm{NIH}$ \\
\hline A. granularum (BTS-39) & $\mathrm{NIH}$ & M. flocculare (Ms42) & MS-LID \\
\hline A. hippikon $(\mathrm{C} 1)^{b}$ & MS-LID & M. gallisepticum (PG-31) & $\mathrm{NIH}$ \\
\hline A. laidlawii (PG-8) & $\mathrm{NIH}$ & M. hyopneumoniae $(\mathrm{J})$ & MS-LID \\
\hline A. modicum (PG-49) & MS-LID & M. hyorhinis (BTS-7) & NIH \\
\hline A. oculi $(19 \mathrm{~L})$ & MS-LID & M. moatsii (MK405) & MS-LID \\
\hline Acholeplasma sp. (72-043) & MS-LID & M. molare $(\mathrm{H} 542)$ & MS-LID \\
\hline Mycoplasma alvi (Ilsley) & MS-LID & M. mycoides subsp. capri (PG-3) & MS-LID \\
\hline M. anatis (1340) & NIH & M. mycoides subsp. mycoides (B3) & MS-LID \\
\hline M. bovigenitalium (PG-11) & NIH & $M$. neurolyticum (type A) & NIH \\
\hline M. bovirhinis (PG-43) & $\mathrm{NIH}$ & M. ovipneumoniae (ST-931) & MS-LID \\
\hline M. bovoculi (M165/69) & MS-LID & M. pneumoniae $(\mathrm{FH})$ & NIH \\
\hline M. canis (PG-14) & $\mathrm{NIH}$ & M. pulmonis ( $\mathrm{PG}-34)$ & $\mathrm{NIH}$ \\
\hline M. capricolum (Calif. kid) & MS-LID & M. putrefaciens (KS-1) & MS-LID \\
\hline M. caviae (G122) & MS-LID & M. sualvi (Mayfield B) & MS-LID \\
\hline M. citelli (RG-2C) & MS-LID & $M$. verecundum (107) & MS-LID \\
\hline M. columborale (MMP-4) & MS-LID & $\begin{array}{l}\text { Mycoplasma sp. (bovine group 7) } \\
\text { (B5P) }\end{array}$ & MS-LID \\
\hline M. conjunctivae (HRC581) & MS-LID & $\begin{array}{l}\text { Mycoplasma sp. (avian group C) } \\
\text { (CKK) }\end{array}$ & MS-LID \\
\hline M. cynos $(\mathrm{H} 831)$ & MS-LID & $\begin{array}{l}\text { Mycoplasma sp. (avian group D) } \\
(\mathrm{SA}-J)\end{array}$ & MS-LID \\
\hline M. dispar $(462 / 2)$ & MS-LID & $\begin{array}{l}\text { Mycoplasma sp. (avian group F) } \\
\text { (WR1) }\end{array}$ & MS-LID \\
\hline M. edwardii (PG-24) & MS-LID & $\begin{array}{l}\text { Mycoplasma sp. (avian group I) } \\
\text { (Iowa 695) }\end{array}$ & MS-LID \\
\hline M. equigenitalium (T37) & MS-LID & $\begin{array}{l}\text { Mycoplasma sp. (flower) } \\
\text { (Melaleuca) }\end{array}$ & MS-LID \\
\hline M. feliminutum (Ben) & MS-LID & $\begin{array}{l}\text { Mycoplasma sp. (lettuce) } \\
\text { (831-C4) }\end{array}$ & MS-LID \\
\hline
\end{tabular}

"Abbreviations: NIH, National Institutes of Health (NIAID-NIH Research Reference Reagent); MS-LID, Mycoplasma Section, Laboratory of Infectious Diseases, NIH.

${ }^{b}$ Conjugated antiserum only used in serological testing.

when examined by Gram-staining techniques or when plated to bacteriological agar.

Filtration studies. A cloned broth culture of strain $72-043$ contained $1.5 \times 10^{7}$ colony-forming units $/ \mathrm{ml}$ before filtration through a series of membrane filters. The number of colony-forming units per milliliter after filtration through membrane filters of 450-, 300-, and $220-\mathrm{nm}$ average pore size were $4.5 \times 10^{6}, 6.0 \times 10^{4}$, and 5.5 $\times 10^{2}$, respectively. Cells did not pass through the 100 -nm filter.

Biochemical and biological properties. The results of the biochemical and biological tests performed on strains 72.043 and S2 are summarized in Table 3. Both strains fermented glucose but not mannose. They hydrolyzed esculin and arbutin, but gave a weak $(1+)$ reaction in the latter test. Neither strain produced carotenoid pigments under the test conditions used. The growth response of strain 72-043 to cholesterol is shown in Table 4. None of the levels of cholesterol tested showed any stimulation of growth, and Tween 80 appeared to exert some inhibitory activity against this strain.

Serological tests. Growth inhibition and plate immunofluorescence tests, with antisera or conjugates prepared to the mycoplasmas listed in Table 1, indicated that these strains were serologically unrelated to previously established Acholeplasma species or to other glucose-fermenting Mycoplasma species. The two strains under examination showed complete serological cross-reactions with each other by both test procedures.

Polyacrylamide gel patterns. A comparison of the cell proteins of strains 72-043 and S2 by polyacrylamide gel electrophoresis is shown in Fig. 3. The patterns of the two strains are similar to each other but appeared to be distinct from those of other Acholeplasma species represented in a collection in the National Institutes of Health laboratory.

DNA characteristics. The melting temperature of the DNA of both acholeplasmas was 


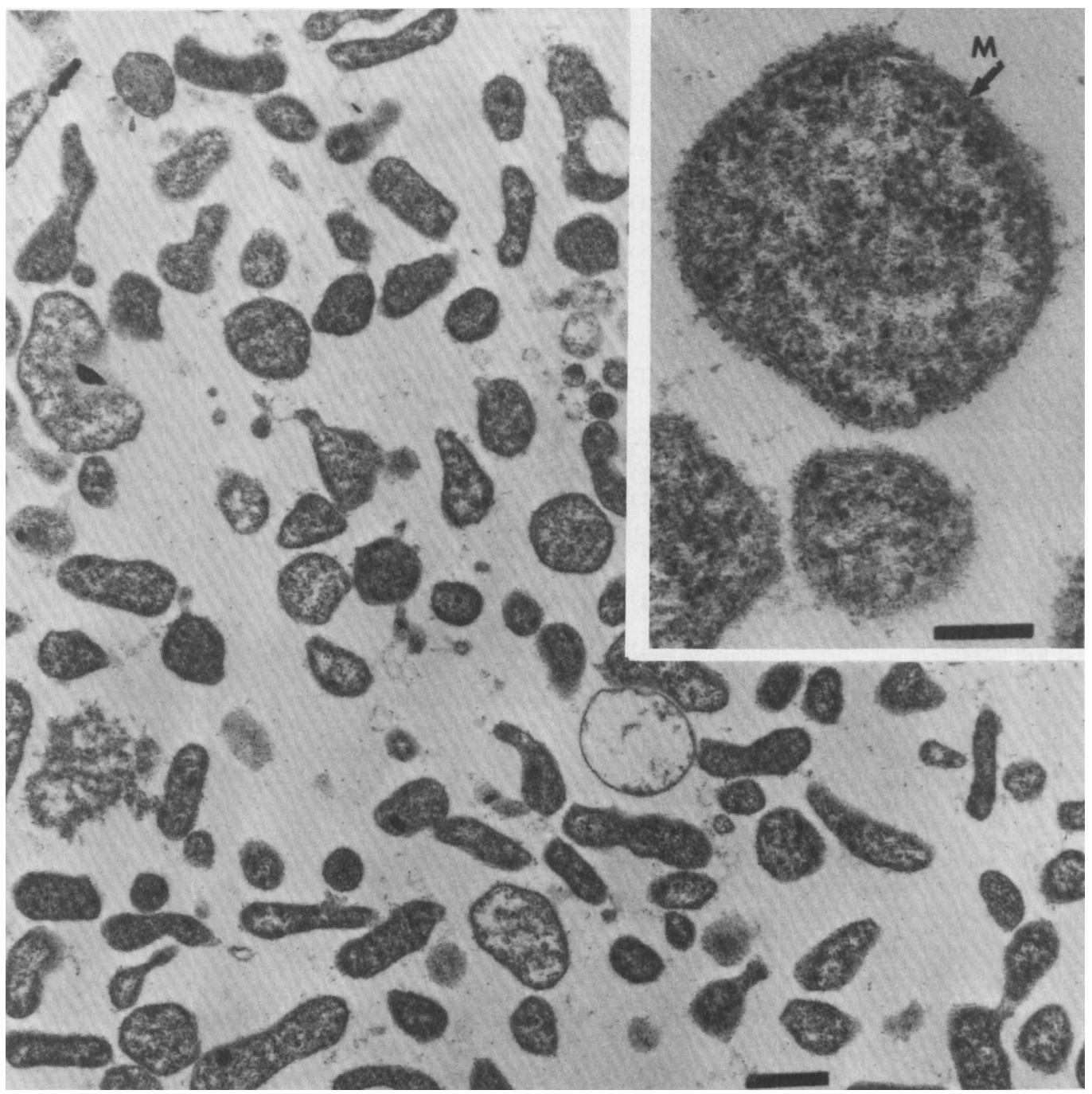

FIG. 1. Electron micrograph of strain 72-043. Thin-section preparation of a 4-day-old culture stained with uranyl acetate. Bar, $500 \mathrm{~nm}$. (Inset) Higher magnification of cell, showing unit membrane (M). Bar, $100 \mathrm{~nm}$.

found to be $79.4^{\circ} \mathrm{C}$, whereas that obtained with $S$. citri was recorded as $76.0^{\circ} \mathrm{C}$. The guanineplus-cytosine content for strains $72-043$ and S2 was calculated to be $34.0 \mathrm{~mol} \%$.

\section{DISCUSSION}

One of the more interesting features of strains $72-043$ and $\mathrm{S} 2$ is their unique growth inhibition when $20 \%$ horse serum is added to the conventional mycoplasma broth base or when certain types of calf serum are used as a serum source. The inhibition by horse serum is probably the result of some specific antibody to these organisms in horse serum, since growth occurred regularly with $20 \%$ agamma horse serum or when the regular horse serum was diluted to 5 or $10 \%$ concentrations in the broth medium. Growth inhibition of strain 72-043 in medium containing 10 to $20 \%$ newborn calf serum or $20 \%$ agamma calf serum suggests the presence of some nonspecific inhibitors other than antibody in these sera, although media prepared with $20 \%$ fetal bovine serum did not exert inhibition. The excellent growth response of the strains to medium containing $20 \%$ fetal bovine serum correlates well with the occurrence of these acholeplasmas in fetal bovine serum or in primary calf kidney cell cultures. In addition, growth inhibi- 
TABLE 2. Effect of various serum supplements or substitutes on the sustained growth of strain $72-043$

\begin{tabular}{|c|c|c|c|}
\hline \multirow{2}{*}{ Supplement } & \multicolumn{3}{|c|}{ Growth (color-changing units $/ \mathrm{ml})^{a}$} \\
\hline & Passage 1 & Passage 5 & Passage 12 \\
\hline None (base medium) ${ }^{b}$ & $10^{3}$ & $10^{1}$ & $\mathrm{NG}$ \\
\hline $0.5 \%$ albumin and $10 \mu \mathrm{g}$ of palmitic acid per $\mathrm{ml}$ & $10^{1 j}$ & $10^{6}$ & $10^{6}$ \\
\hline $1 \%$ bovine serum fraction & $10^{4}$ & $10^{4}$ & $10^{9}$ \\
\hline $20 \%$ horse serum & $10^{1}$ & NG & NG \\
\hline $10 \%$ horse serum & $10^{y}$ & $10^{*}$ & $10^{4}$ \\
\hline $5 \%$ horse serum & $10^{4}$ & $10^{9}$ & $10^{9}$ \\
\hline $20 \%$ agamma horse serum & $10^{4}$ & $10^{9}$ & $10^{9}$ \\
\hline $20 \%$ newborn calf serum & $10^{1}$ & NG & NG \\
\hline $10 \%$ newborn calf serum & $10^{2}$ & NG & NG \\
\hline $5 \%$ newborn calf serum & $10^{9}$ & $10^{9}$ & $10^{9}$ \\
\hline $20 \%$ agamma calf serum & $10^{2}$ & NG & NG \\
\hline $10 \%$ agamma calf serum & $10^{9}$ & $10^{9}$ & $10^{9}$ \\
\hline $20 \%$ fetal calf serum & $10^{9}$ & $10^{9}$ & $10^{4}$ \\
\hline
\end{tabular}

"The inoculum for the first passage was a 24-h-old culture of strain $72-043$ grown in $1 \%$ serum fraction broth at $37^{\circ} \mathrm{C}$. Tenfold dilutions were made in each medium, and the results were recorded as the higest dilution in which turbidity and a color change in the $\mathrm{pH}$ indictor occurred within 7 days at $37^{\circ} \mathrm{C}$. NG, No growth.

${ }^{b}$ The base medium was composed of mycoplasma broth base with $10 \%$ of a $25 \%$ solution of fresh yeast extract, $0.5 \%$ glucose, and $0.002 \%$ phenol red.
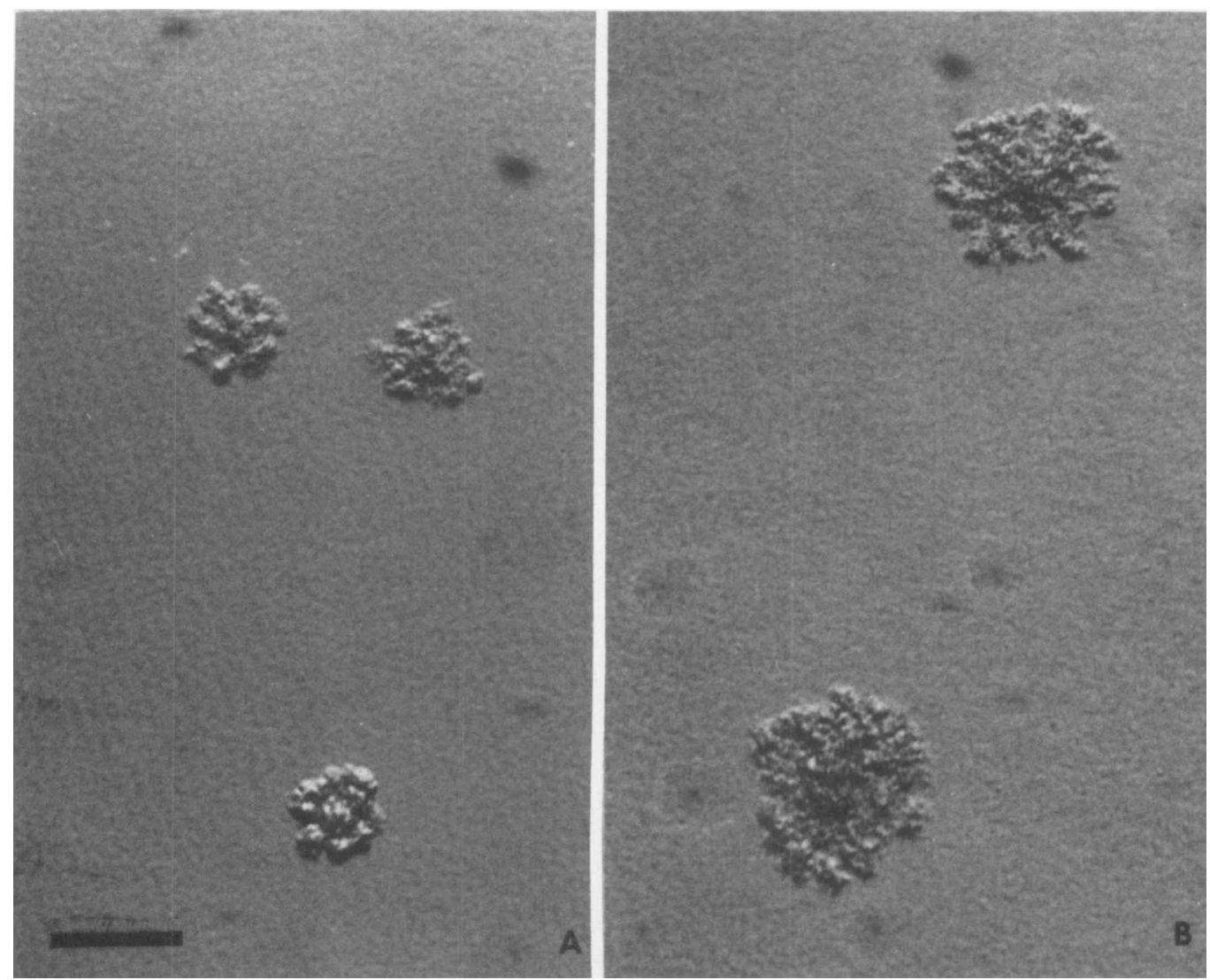

Fig. 2. Colonies of strain $72-043$ grown on agar for 2 days at $37^{\circ} \mathrm{C}$ in an atmosphere of $95 \% \mathrm{Nplus} 5 \% \mathrm{CO}_{2}$. (A) Serum-free agar; (B) 1\% bovine serum fraction agar. Bar, $100 \mu \mathrm{m}$. 
TABLE 3. Biochemical and biological characteristics of strains $72-043$ and $S 2$

\begin{tabular}{|c|c|}
\hline Property & Result \\
\hline Fermentation of glucose & + \\
\hline $\begin{array}{l}\text { Fermentation of man- } \\
\text { nose }\end{array}$ & - \\
\hline Hydrolysis of arginine & - \\
\hline Hydrolysis of urea & - \\
\hline Sterol requirement & - \\
\hline $\begin{array}{l}\text { Susceptibility to } 1.5 \% \\
\text { digitonin }\end{array}$ & $-(1-2 \mathrm{~mm})$ \\
\hline Carotenoid production & - \\
\hline Hydrolysis of esculin & + \\
\hline Hydrolysis of arbutin & $1+($ weak $)$ \\
\hline Phosphatase production & - \\
\hline $\begin{array}{l}\text { Tetrazolium reduction } \\
\text { (aerobic/anaerobic) }\end{array}$ & $\pm /+$ \\
\hline Film and spot reaction & - \\
\hline $\begin{array}{l}\text { Liquefaction of coagu- } \\
\text { lated serum }\end{array}$ & - \\
\hline $\begin{array}{l}\text { Hemadsorption (guinea } \\
\text { pig erythrocytes) }\end{array}$ & P \\
\hline Colonies on agar & Rough and irregular \\
\hline Preferred atmosphere & Anaerobic \\
\hline Preferred temp & $37^{\circ} \mathrm{C}$ (growth at $23^{\circ} \mathrm{C}$ ) \\
\hline $\mathrm{G}+\mathrm{C}$ of DNA $(\mathrm{mol} \%)^{a}$ & 34.0 \\
\hline
\end{tabular}

${ }^{a} \mathrm{G}+\mathrm{C}$, Guanine plus cytosine.

TABLE 4. Effect of cholesterol on growth of strain $72-043$ in serum-free medium

\begin{tabular}{cc}
\hline Cholesterol in medium $(\mu \mathrm{g} / \mathrm{ml})$ & Cell protein $(\mathrm{mg})^{a}$ \\
\hline $0^{b}$ & 0.08 \\
$0^{c}$ & 2.00 \\
$0^{d}$ & 0.82 \\
1.0 & 0.65 \\
5.0 & 0.92 \\
10.0 & 0.84 \\
20.0 & 0.84 \\
Control $^{e}$ & 5.74 \\
\hline
\end{tabular}

a Protein in cell pellets obtained from $100 \mathrm{ml}$ of medium.

${ }^{b}$ Serum-free medium.

' Serum-free medium with $0.5 \%$ albumin and $10 \mu \mathrm{g}$ of palmitic acid per $\mathrm{ml}$.

${ }^{d}$ Serum-free medium with albumin, palmitic acid, and $0.01 \%$ Tween 80 .

${ }^{e}$ Medium containing $1 \%$ bovine serum fraction.

tion in media containing $20 \%$ horse serum might explain why these acholeplasmas, of suspected bovine origin, have not been recovered earlier, since most isolation media for mycoplasmas consist of $20 \%$ horse serum. Finally, cultural studies performed with these two organisms showed clearly that, whereas they did not require serum or cholesterol as a growth requirement, sustained growth occurred in serum-free broth only when supplements of albumin and palmitic acid were made. These results are similar to some of our earlier findings, which showed that additions of fatty acid (Tween 80 ) and albumin produced remarkable increases in growth of Acholeplasma axanthum strains $(28,29)$.

The morphology, filterability, and absence of

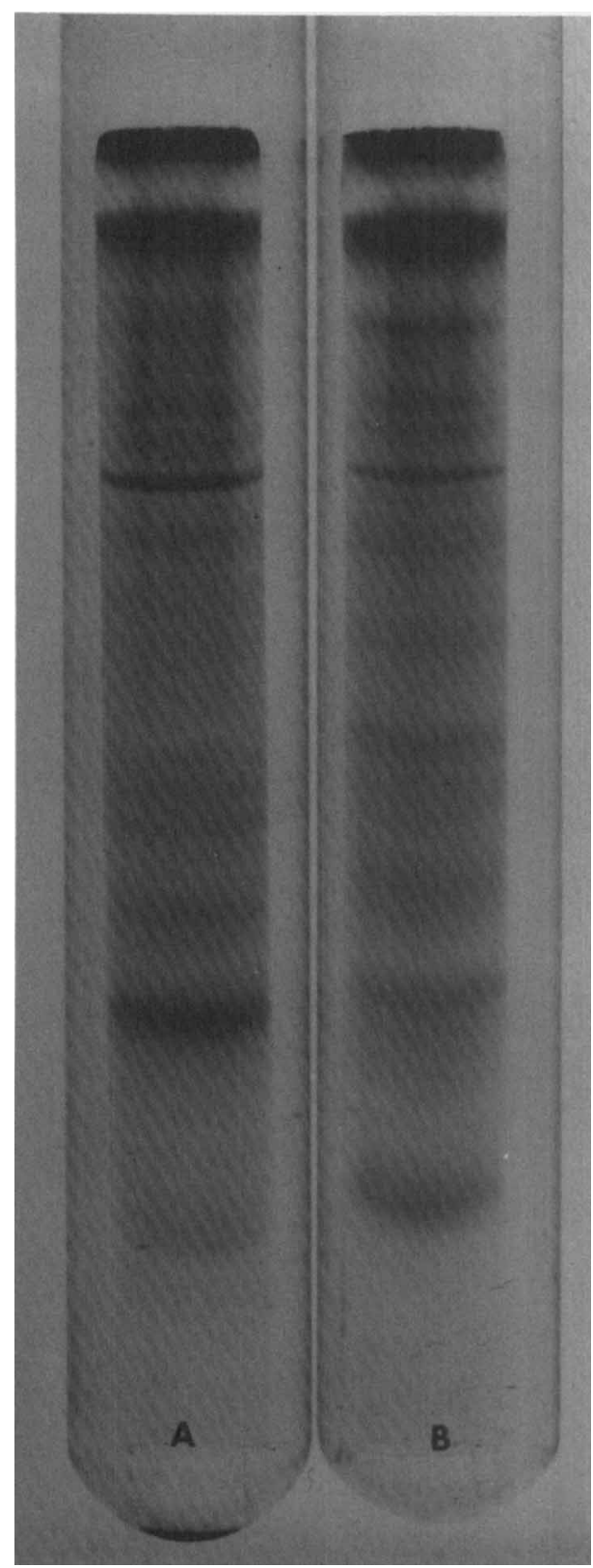

FIG. 3. Electrophoretic patterns of cell proteins of strains 72-043 (A) and S2 (B). 
reversion to bacteria of these strains offer substantial evidence that these organisms belong to the class Mollicutes. Their lack of sterol requirement for growth and ability to grow aerobically place them in the family Acholeplasmataceae and the genus Acholeplasma. Extensive serological tests performed in this study indicate that these strains are unrelated to any of the seven established Acholeplasma species or to $\mathrm{Myco}$ plasma species that ferment carbohydrates. Further evidence that these acholeplasmas represent a new and distinct species is provided in the nucleic acid hybridization comparisons mentioned previously (2). We believe, therefore, that these organisms represent a new species and propose that they be designated Acholeplasma morum (L. noun morum, mulberry). The species epithet chosen relates to the mulberry-like appearance of agar colonies of the organism. Strain 72-043 is designated as the type strain. A cloned line of this strain has been deposited in the American Type Culture Collection as ATCC 33211.

\section{ACKNOWLEDGMENTS}

We thank $R$. H. Leach for generosity in supplying the S2 strain. We are also grateful to R. M. Cole and T. J. Popkin for generous assistance in the preparation, examination, and photography of specimens for electron microscopy, and to J. M. Bove and C. Saillard for kindness in doing the DNA determinations. We also acknowledge the technical assistance of Colis Blood.

\section{REPRINT REQUESTS}

Address reprint requests to: D. L. Rose, Mycoplasma Section, National Institute of Allergy and Infectious Diseases, Bethesda, MD 20205.

\section{LITERATURE CITED}

1. Aluotto, B. B., R. G. Wittler, C. O. Williams, and J. E. Faber. 1970. Standardized bacteriologic techniques for the characterization of Mycoplasma species. Int. J. Syst. Bacteriol. 20:35-58.

2. Aulakh, G. S., J. G. Tully, and M. F. Barile. 1979. Differentiation among some acholeplasmas by nucleic acid homology. Curr. Microbiol. 2:91-94.

3. Bak, A. L., F. T. Black, C. Christiansen, and E. A. Freundt. 1969. Genome size of mycoplasmal DNA. Nature (London) 224:1209-1210.

4. Barile, M. F., and J. Kern. 1971. Isolation of Mycoplasma arginini from commercial bovine sera and its implication in contaminated cell cultures. Proc. Soc. Exp. Biol. Med. 138:432-437.

5. Bradbury, J. M. 1977. Rapid biochemical tests for characterization of the Mycoplasmatales. J. Clin. Microbiol. 5:531-534.

6. Clyde, W. A., Jr. 1964. Mycoplasma species identification based upon growth inhibition by specific antisera. J. Immunol. 92:958-965.

7. Cole, R. M., T. J. Popkin, R. J. Boylan, and N. H. Mendelson. 1970. Ultrastructure of a temperature-sensitive Rod mutant of Bacillus subtilis. J. Bacteriol 103:793-810.

8. Cunningham, S. (ed.). 1978. NIAID catalog of research reagents, p. 859-959. Department of Health, Education and Welfare publ. no. (NIH) 78-899. National Institutes of Health, Bethesda, Md.

9. Del Giudice, R. A., N. F. Robillard, and T. R. Carski. 1967. Immunofluorescence identification of $\mathbf{M y c o}$ plasma on agar by use of incident illumination. J. Bacteriol. 93:1205-1209.

10. Ernø, H., and L. Stipkovits. 1973. Bovine mycoplasmas: cultural and biochemical studies. II. Acta Vet. Scand. 14: 450-463.

11. Freundt, E. A., B. E. Andrews, H. Ernø, M. Kunze, and F. T. Black. 1973. The sensitivity of Mycoplasmatales to sodium polyanethol-sulfonate and digitonin. Zentralbl. Bakteriol. Parasitenkd. Infektionskr. Hyg. Abt. 1 Orig. 225:104-112.

12. Herring, P. K., and J. D. Pollack. 1974. Utilization of $\left[1-{ }^{14} \mathrm{C}\right.$ ]acetate in synthesis of lipids by acholeplasmas. Int. J. Syst. Bacteriol. 24: 73-78.

13. Junca, P., C. Saillard, J. Tully, O. Garcia-Jurado, J.-R. Degorce-Dumas, C. Mouches, J.-C. Vignault, R. Vogel, R. McCoy, R. Whitcomb, D. Williamson, J. Latrille, and J. M. Bové. 1980. Caractérisation de spiroplasmes isolés d'insectes et de fleurs de France continentale, de Corse et du Maroc. Proposition pour une classification des spiroplasmes. C. R. Acad. Sci. 290:1209-1212.

14. Manchee, R. J., and D. Taylor-Robinson. 1968. Haemadsorption and hemagglutination by mycoplasmas. $J$. Gen. Microbiol. 50: 465-478.

15. Neimark, H. C. 1973 . Molecular evolutionary studies on mycoplasmas and acholeplasmas. Ann. N.Y. Acad. Sci. 225: 14-21.

16. Pollack, J. D. 1975. Localization of reduced nicotinamide adenine dinucleotide oxidase activity in Acholeplasma and Mycoplasma species. Int. J. Syst. Bacteriol. 25: $108-113$.

17. Pollack, J. D. 1978. Differentiation of Mycoplasma and Acholeplasma. Int. J. Syst. Bacteriol. 28: 425-426.

18. Pollack, J. D., S. Razin, and R. C. Cleverdon. 1965. Localization of enzymes in Mycoplasma. J. Bacteriol. 90: $617-622$.

19. Razin, S. 1968. Mycoplasma taxonomy studies by electrophoresis of cell proteins. J. Bacteriol. 96: 687-694.

20. Razin, S., and J. G. Tully. 1970. Cholesterol requirement of mycoplasmas. J. Bacteriol. 102: 306-310.

21. Rose, D. L., J. G. Tully, and E. V. Langford. 1978. Mycoplasma citelli, a new species from ground squirrels. Int. J. Syst. Bacteriol. 28: 567-572.

22. Saglio, P., M. Lhospital, D. Laflèche, G. Dupont, J. M. Bové, J. G. Tully, and E. A. Freundt. 1973. Spiroplasma citri gen. and sp. n.: a mycoplasma-like organism associated with "stubborn" disease of citrus. Int. J. Syst. Bacteriol. 23:191-204.

23. Schwöbel, W., and R. H. Leach. 1970. Eine Mycoplasma laidlawii nahestehende mykoplasmenart aus primären Kälbernierenkulturen. Zentralbl. Bakteriol. Parasitenkd. Infektionskr. Hyg. Abt.l Orig. 214:495-506.

24. Subcommittee on the Taxonomy of Mollicutes. 1979 Proposal of minimal standards for descriptions of new species of the class Mollicutes. Int. J. Syst. Bacteriol. 29: 172-180.

25. Tully, J. G. 1979. Special features of the acholeplasmas, p. 431-449. In M. F. Barile and S. Razin (ed.), The mycoplasmas, vol. 1. Cell biology. Academic Press, Inc., New York

26. Tully, J. G., M. F. Barile, D. G. ff Edward, T. S. Theodore, and H. Ernø. 1974. Characterization of some caprine mycoplasmas, with proposals for new species, Mycoplasma capricolum and Mycoplasma putrefaciens. J. Gen. Microbiol. 85:102-120.

27. Tully, J. G., and S. Razin. 1968. Physiological and serological comparisons among strains of Mycoplasma 
granularum and Mycoplasma laidlawii. J. Bacteriol. 95:1504-1512.

28. Tully, J. G., and S. Razin. 1969. Characteristics of new sterol-nonrequiring Mycoplasma. J. Bacteriol. 98:970978.

29. Tully, J. G., and S. Razin. 1970. Acholeplasma axan. thum sp.n.: a new sterol-nonrequiring member of the Mycoplasmatales. J. Bacteriol. 103:751-754.

30. Williams, C. O., and R. G. Wittler. 1971. Hydrolysis of aesculin and phosphatase production by members of the order Mycoplasmatales which do not require sterol. Int. J. Syst. Bacteriol. 21: 73-77. 